\title{
Review of the Impact of Tax Policy on Renewable Energy Development in China
}

\author{
Jianfei Shen ${ }^{1, a}$, Yuan Wang ${ }^{2, b}$, Suli Yan ${ }^{3, c}$ \\ ${ }^{1}$ North China Electric Power University, China \\ ${ }^{2}$ North China Electric Power University, China \\ ${ }^{3}$ North China Electric Power University, China \\ b1173365527@qq.com,
}

Keywords: China ,Tax Policy, Renewable Energy Development

Abstract. As one of the important public means of Government's macro-controls, tax policy has played an important role in supporting the new energy industry development. Therefore, using a variety of means, especially macro-fiscal and tax policies, to promote new energy optimization in industrial structure upgrading and healthy development is a better way to solve a range of energy issues today. For this reason, this paper analyzes impact of China's tax policies on the renewable energy industry's present situation, and proposes tax proposals for the development of renewable energy industry in China.

\section{Introduction}

Since the 21st century, the harmonious development of economy and environment has become a main topic all around the world. Energy is an important material basis for maintaining sustainable and effective economic development, but it is also one of the main sources of pollution. So, in the face of imbalance of the world's energy consumption structure, the low energy efficiency, the sharp conflicts of the energy supply and demand, countries all over the world should improve the energy legislation system and tax system, adding the new energy development into the national development strategies to seek the sustainable economic development and security of energy supply [1]. China, as the country occupying the $22.4 \%$ of the world's energy consumption, gives a positive government guidance and policy support on the development of new energy sources [2]. It has been highlighted in the 'Report to the Eighteenth National Congress of the Communist Party of China' that we should promote green, circular, low-carbon development with promoting the revolution in energy production and consumption [3].

\section{The development of renewable energy in China}

China's renewable energy with great variety, wide distribution, large reserves and so on, has the advantages and resources to carry out large-scale development and the potential of excellent marketing. In the background of economic globalization, China will be able to lay a solid material foundation for China's future economic development through international cooperation, the introduction of advanced technology and experience and the enhancement of independent innovation. In 2004, China's total energy consumption reached 213456 (million tons), in which renewable energy 19637.95 (million tons), 9\% of renewable energy in total energy consumption. As shown in table 2.1, from 2004 to 2013, renewable energy supports national policies to achieve development by leaps and bounds, by 2013, the total renewable consumption 58500 (million tons) take 16\% percent of total energy consumption. Just in 9 years, renewable energy consumption in China has grown by almost 200\% [4], which not only shows China's great potential in renewable energy, but also reflects the tremendous achievements in China's socialist modernization construction.

At present, China has become the world's largest energy consumer and the third largest importer of energy. Renewable energy, as an important source of energy resources in meeting energy demand, improving energy consumption structure and alleviating environmental pollution, has made an 
outstanding contribution. China has vast territory and abundant resources, particularly it has rich renewable energy resources. In the planning of Twelve-Five, it is expected in 2015 that, China's hydroelectric, wind power, solar energy and biomass power generation will reach 29580 (million tons), 6180 (million tons), 810 (million tons), 2430 (million tons).[5]

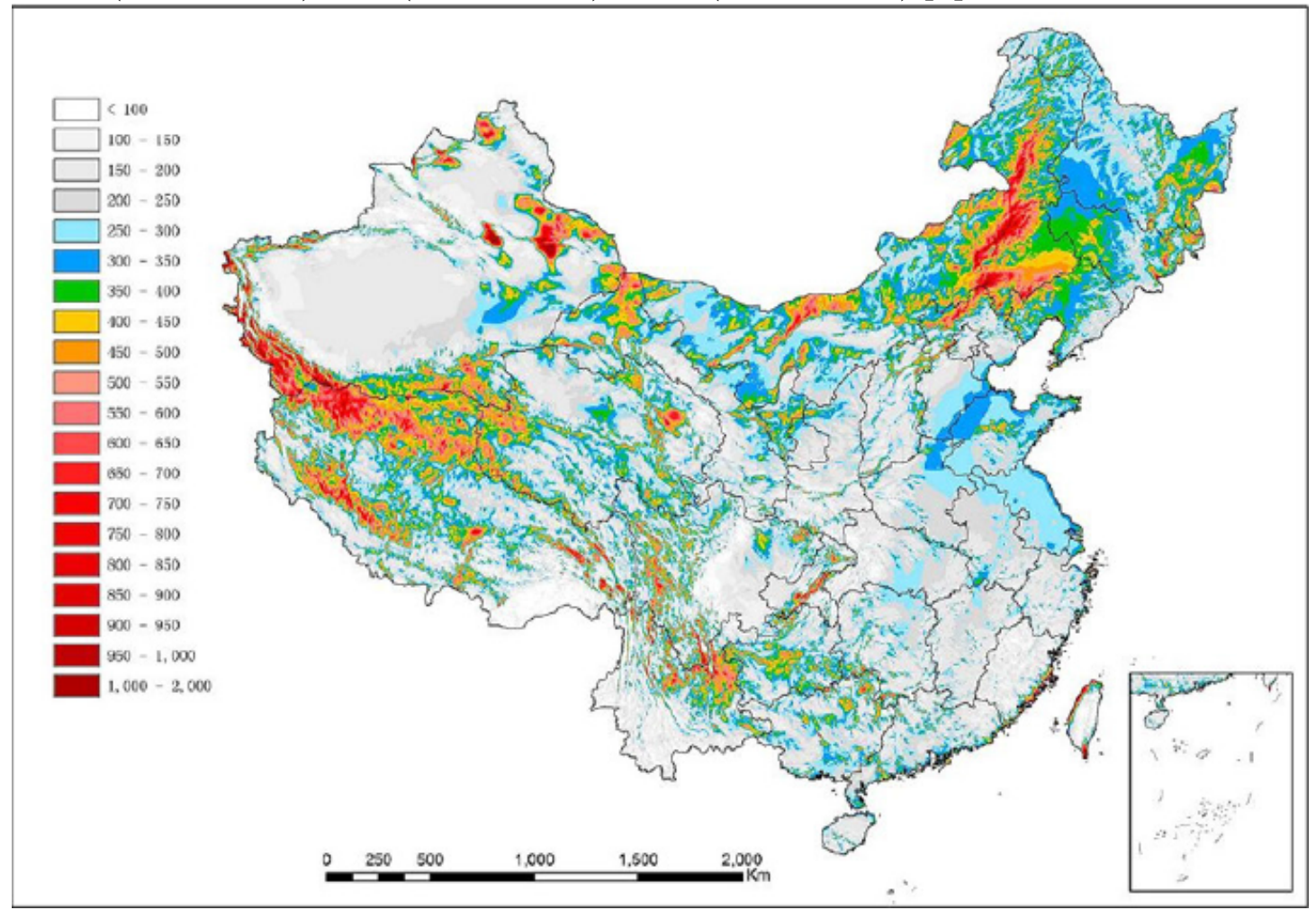

Figure 2.1 distribution of wind energy resources in China



Figure 2.2 horizontal global solar radiation in China 
China is rich in wind energy resources, potential of which is above 3 billion-kilowatt. In addition, at the depth of less than 50 metres from the sea, actual installed capacity of wind power is about 500 million-kilowatt. In view of the potential of wind energy resource and utilization of land and sea area and under the present conditions of wind turbine technology, wind power could be the future of energy and an important part of the power structure. Figure 2.1 shows the distribution of wind energy resources in China [6]. As for solar power, over the next 40 years' technological innovation and large-scale development as well as other supporting advances in technology, China's "independence, self-reliance, low-carbon, sustainable" energy system will become one of the main energy sources. Solar radiation in China is rich in resources, and in a distribution of "plateau than the western plains, dry area is larger than the Eastern humid region". Among them, the most abundant is on the Tibetan plateau, with total annual radiation dose is more than $1800 \mathrm{kWh} / \mathrm{m}^{2}$. In some areas, it's even more than $2000 \mathrm{kWh} / \mathrm{m}^{2}$. Resources are relatively low in the Sichuan basin, annual total amount of radiation at about $1000 \mathrm{kWh} / \mathrm{m}^{2}$. Fundamental objectives of China's solar energy development has been expected that in the year of 2020, 2030 and 2050, solar energy will replace fossil fuels over 150 million, 310 million and 860 million tons of standard coal, which respectively provides power 150 billion, 510 billion and 2.1 trillion $\mathrm{kWh}$. Figure 2.2 has shown horizontal global solar radiation in China.

\section{China's energy consumption structure in2004-2013}

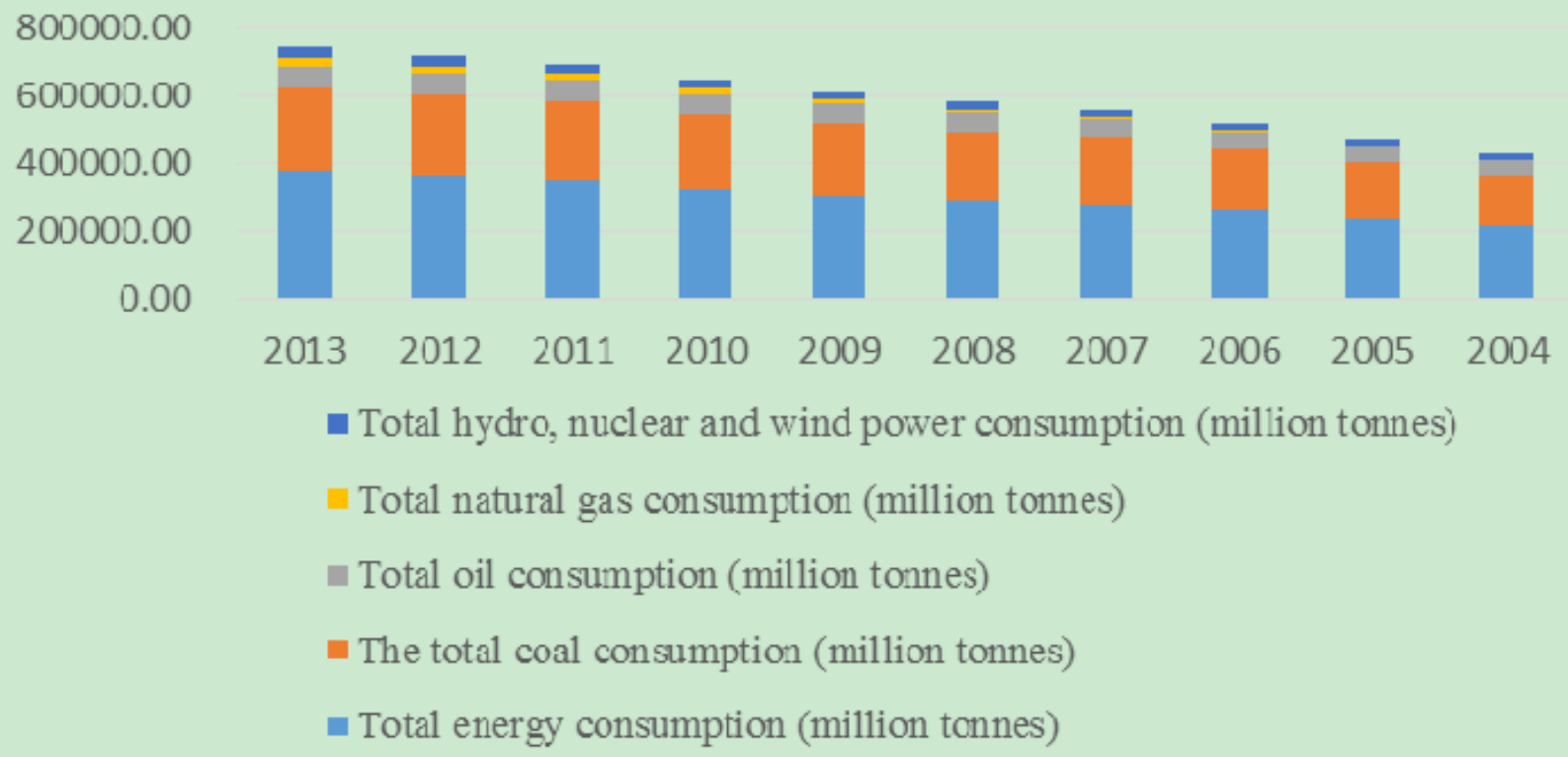

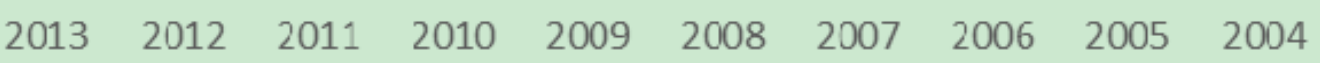

- Total hydro, nuclear and wind power consumption (million tonnes)

Total natural gas consumption (million tonnes)

- Total oil consumption (million tonnes)

- The total coal consumption (million tonnes)

- Total energy consumption (million tonnes)

Table 2.12004-2013 of China's energy consumption structure (Data source: National Statistical Office)

\section{Problems and suggestions for the new energy tax policy in China}

Problems. With the sustained rapid economic growth and changes in the international energy market, China is facing a lot of serious energy problems. Comrade Deng Xiaoping, Chief Architect of the reform and opening up has pointed out that, "diversification of energy, hydropower, thermal power, nuclear power, solar energy, biogas, tidal and wind power, all kinds of energy develop all together. "[7] Tax policy is one of the most effective policy tools to guide and support the Government's new energy industry development. However, current energy and taxation policies in China fail to meet the nation's energy development strategy, mainly reflected in the following three aspects: 
(1)Has not yet to take full advantage of tax regulation of energy prices for energy saving and emission reduction, and is far from energy-saving goals.

(2)Tax rate level with the object of assessment is independent of the degree of environmental protection and not conducive to encouraging environmental protection products or non-environmental investigation, without reaching the environmental objectives.

(3) Due to the low energy tax, the tax base is relatively narrow and not work well with countries to reduce coal consumption, increasing the consumption of natural gas and other clean energy strategies of optimizing energy structure.

Suggestions. Based on the above statement, the recommendations on China's energy tax policy are as follows:

(1)Mainly depend on the indirect benefits. China is in the early stages of industrial development and industrial structure improvement, resulting in that indirect preferential policies like accelerated depreciation can better support industry and play an important role in the market.

(2)Develop tax policies to encourage high-carbon industries to transform to low-carbon industries and, for example, high-carbon industries through technological innovation to reduce carbon emissions, which can corporate income tax relief.

(3)Impose tax deduction on enterprises engaged in energy-saving industries. For example, as for the enterprises which use the national energy-saving material manufacture and processing, their actual investment in new equipment for the year can deduct the corporate income tax.

\section{Summary}

Energy and sustainable development is a matter of overall strategic issues in the development of the whole country involved every aspect of energy-related areas. It will be of great significance for the governments to make reasonable energy tax policy for China's economy and the long-term sustainable development of society. China lags behind the requirements of the sustainable development on energy tax policy, and tax policy of market-based incentives and constraints has not been fully realized. Therefore, in the process of improving the tax system to promote renewable sources of energy development, China still has a long way to go.

\section{References}

[1] Fadong Chen.Research on Tax Policies of Supporting the Development of New Energy Industry.2012.11

[2] BP-statistical-review-of-world-energy-2014-full-report

[3] Report to the Eighteenth National Congress of the Communist Party of China

[4] NBS network

[5] the China renewable Twelve-Five plan survey, National Energy Board, National Centre for renewable energy

[6] Chinese wind energy roadmap 2050, Energy Research Institute, national development and Reform Commission, 2011.10

[7] China renewable energy development and utilization status and development, of the energy of the 1999 10th issue, Zhang Zhengmin, Zhu Junsheng 